\title{
EVALUATION OF SOME ROSA CULTIVARS UNDER TRANSYLVANIA CLIMATIC CONDITIONS
}

\author{
Timea Hitter (Buru) ${ }^{1}$, Zsolt Szekely-Varga ${ }^{1}$, Istvan Lorand Csiki ${ }^{1}$, Erzsebet Buta ${ }^{1}$, Maria Cantor ${ }^{1, *}$ \\ ${ }^{1}$ University of Agricultural Sciences and Veterinary Medicine Cluj-Napoca, Department of Horticulture and \\ Landscaping, St. Calea Manastur, No. 3-5, 400372 Cluj-Napoca, Romania
}

\begin{abstract}
Roses have been always among the world's most favourite and admired flowers because of their unusual beauty. The study was conducted at the 'Super Rosa Csiki Association located in Ciumbrud, Alba (Romania), nursery in which annually, many valuable cultivars from abroad are grafted, for economic purposes. The research focused on the evaluation of phonological behavior and main morpho-decorative characters regarding 10 Rosa hybrida cultivars namely: 'Acapella - Tantau', 'Caprice De Meilland ', 'Imperetrice Farah', 'Burgund 81', 'Monika', 'Romstar', 'White Success', 'Vivaldi', 'Black Velvet', 'Holstein Perle'. Various determinations and observations were carried out on cultivars based on an evaluation scale from 1 to 100 points, analyzing 13 different characters. The obtained results revealed after the evaluation, cultivars as 'Monika', 'Romstar', 'Black Velvet' and 'Burgund 81 'obtained the highest score, over 85 points. These varieties are recommended for the future to be cultivated as cut flowers used in floral arrangements, but also for landscape design or genetic resources for breeding works.
\end{abstract}

Keywords: characteristics morpho-decorative, evaluation scale, Rosa, varieties

\section{INTRODUCTION}

Nowadays the wild or cultivated rose is spread all over the globe, and it is impressing and producing deep emotions through everything that belongs to it these flowers (Băla, 2012). Rose ranks first among the top ten cut flowers in the international flower market (Shivaprasad et al., 2016).

The rose is one of the world's most popular flowers. Roses are commonly grown as cut flowers, potted plants, or some species in home gardens. Herodotus mentions the 60-petalled rose of the legendary King Midas and Theophrastus describes various colors and ways of propagating of the roses (Haenchen, 2008).

The production of cut roses has been moved from Northern Latitudes to areas near to the Equator, which have a higher altitude, equal day/night durations, high light intensity, cooler temperatures, and economically the cultivation of the roses is cheaper the in other areas (Kim, 2007).

The evolution of the genus Rosa, dates from about $2700 \mathrm{BC}$. Around $500 \mathrm{BC}$, Confucius had described the roses in the imperial gardens.

Roses are one of the most popular plants in the horticulture industry, featuring a variety of plant forms, flower forms, colors, and scents that make them versatile landscape plants (Mangandi et al., 2013). 
Researchers have always been creating new varieties and diversified existing ones, in an explosion of shapes and colours, as no other plant species it is known on Earth (Ciupa and Szabo, 2011).

Rose production for cut flower in the United States is reported to have occurred first around 1850 when the sale of a few buds of the cultivar 'Hermosa', described as a blush-pink fragrant China rose, was made. The famous 'American Beauty' cultivar was introduced about 1880 and for years remained one of the most popular cut flower roses forced for Christmas bloom (Hasek, 1980). Nowadays hundreds of rose cultivars are created by breeders and have been introduced and are produced by most rose growers (over 25000 cultivars - Wagner, 2002). The major world producers of roses are China, Ecuador, Colombia, Kenya and the Netherlands. The main exporting countries are Ecuador, Colombia and Kenya.

The World Roses Federation organizes annual meetings and conventions with its members, where the assortments of rose novelties and technology that have appeared worldwide are presented (http://www.worldrose.org/).

In Romania, the rose culture has an old tradition, however, only at the end of the XVII ${ }^{\text {th }}$ century marks a new era of landscape architecture, creating the most important parks throughout the country, purchasing hundreds of ornamental plants, brought from other continents. For most of us seeing roses in every city or village, either in public or private spaces it's a common thing.

After the Second World War in Romania appeared about 70 new varieties of roses, created only by 3 breeders (Wagner Şt., Roman Gabriela, Argatu Constanța), most of them are Thea hybrida group (Wagner, 2013).

The Thea hybrida group of roses is the most well-known and appreciated group, the plants are in the form of a shrub as well as in a standard form. They bloom abundantly all summer; have very varied colors, with flowers of different sizes, pleasantly fragrant. Glossy leaves and the shoots are red, and they are resistant to frost (Wagner, 2002).

Production of rose seedlings at nurseries Ciumbrud, Alba County is already a tradition. Producers of roses have inherited this occupation from their grandparents and parents and they want to pass it over to their descendants.

Modern roses, specifically those of the horticultural class of hybrid teas, are most demand and the growers in this area of Transylvania are constantly concerned with the multiplication of the most valuable varieties of roses to promote in the cultivation. Annual the most valuable rose varieties brought from abroad are grafted due to the high demands that exist in our country but are also produced for export, and it is an important source of income for producers.

\section{MATERIALS AND METHODS}

This study was conducted at the 'Super Rosa Csiki` Association in Ciumbrud (Figure 1), Alba County, during the years 2018-2019.

The association `Super Rosa Csiki Ciumbrud was established in 2002 having as object of work the production of the planting material of roses, fruit trees, but also their commercialization. From its establishment until now, the company has grown a lot both in terms of area and its endowment with modern machines and equipment, as well as well-trained staff. The grandparents and parents of the Csiki family, together with the local citizens, went around the country to graft roses, since 1957 (Cantor, 2012). 


\begin{tabular}{lrr}
\hline & $\begin{array}{c}\text { Current Trends in Natural Sciences } \\
\text { Vol. 9, Issue 17, pp. 153-159, 2020 } \\
\end{array}$ & \\
& https://doi.org/10.47068/ctns.2020.v9i17.018 & Current Trends in Natural Sciences (CD-Rom) \\
Current Trends in Natural Sciences (on-line) & ISSN: 2284-9521 \\
ISSN: 2284-953X & & ISSN-L: 2284-9521 \\
ISSN-L: 2284-9521 & \\
\hline
\end{tabular}

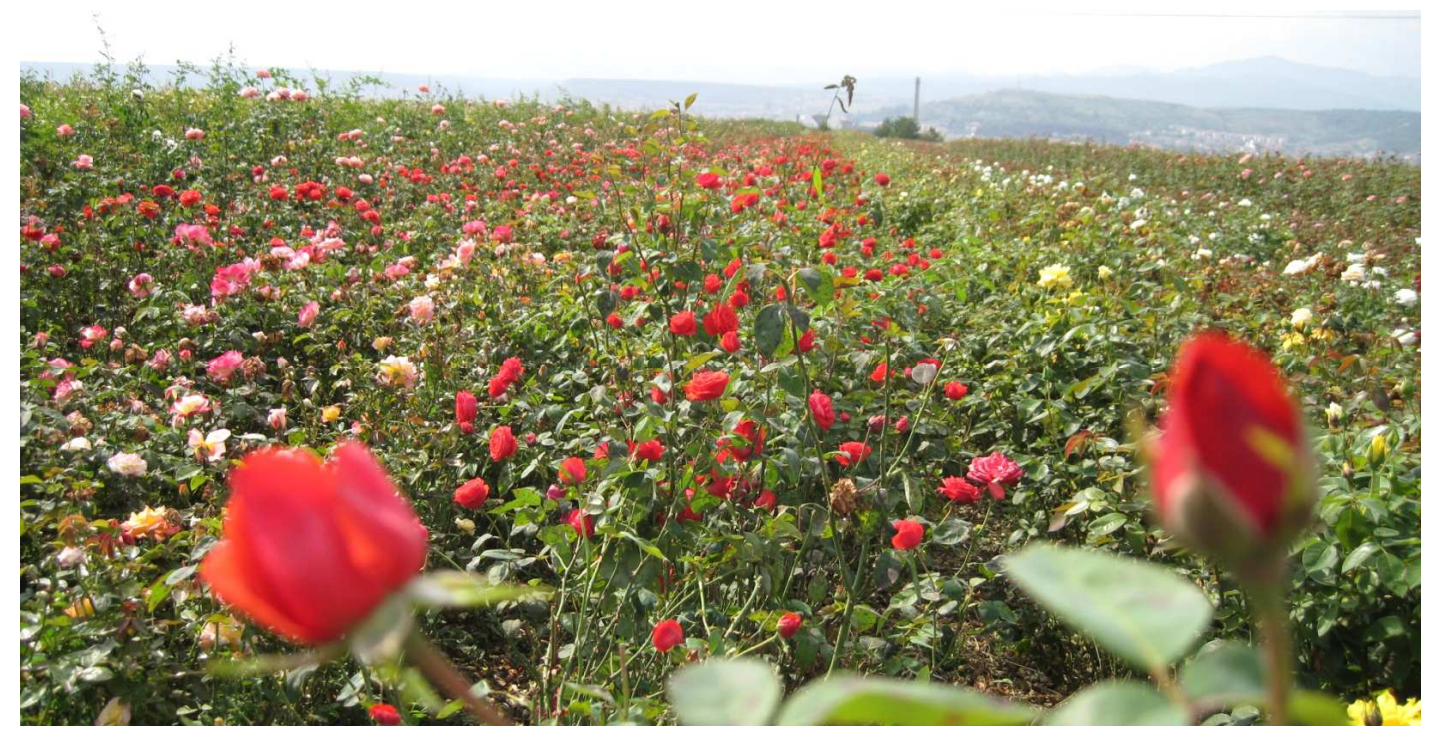

Figure 1. Rose culture field - 'Super Rosa Csiki`Association Ciumbrud

The large number of rose cultivars, but also the multiple types of uses make it necessary to choose the best varieties, which are corresponding the best to the ecological conditions of Romania.

In this context, ten cultivars of Rosa hybrida Thea produced in this nursery namely (Figure 2): 'Acapella - Tantau', 'Caprice De Meilland', 'Imperetrice Farah', 'Burgund 81', 'Monika', 'Romstar', 'White Success', 'Vivaldi', 'Black Velvet' and 'Holstein Perle' were check out through an specific evaluation scale from 1 to 100 points (Wagner, 2002), analyzing 13 characters: leaves, shrub shape, vigor of the bush, flower pedicel, flowering intensity, shape of the bud, shape of the open flower, flower durability, opening color, flowering color, the petals drops, perfume and disease resistance.
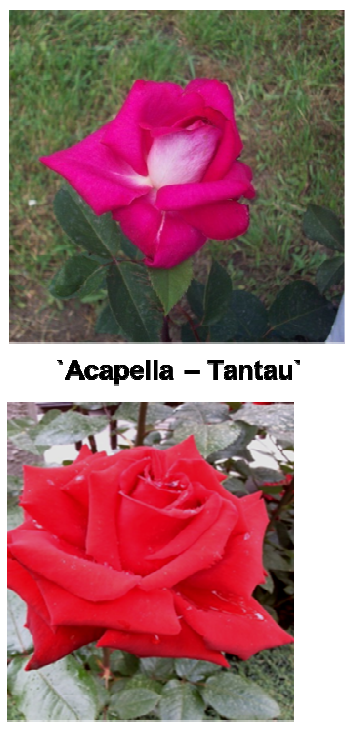

'Romstar'

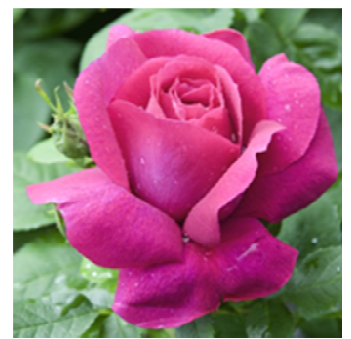

'Caprice De Meilland'

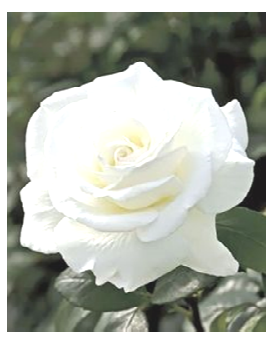

'White Succes'

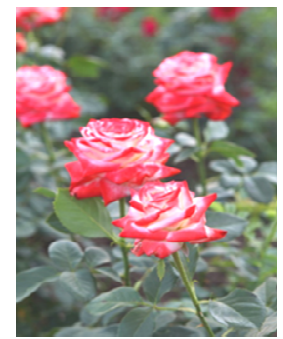

'Imperetrice Farah"

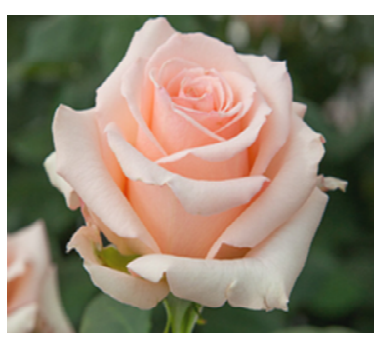

'Vivaldi'

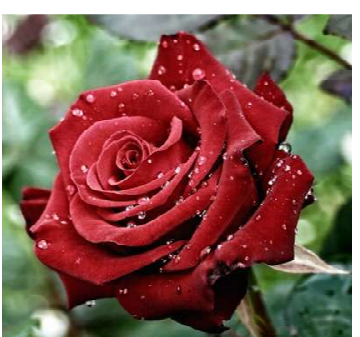

'Burgund'81'

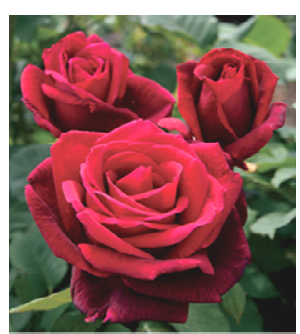

'Black Velvet'

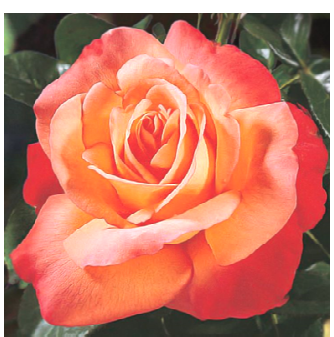

'Monica'

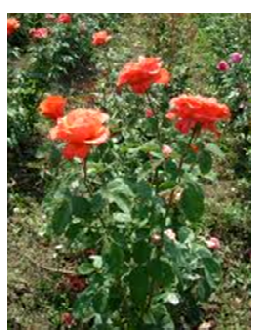

"Holstein perle"

Figure 2. The cultivars of Rosa hybrida TH studied at`Super Rosa Csiki Association Ciumbrud 


\section{Current Trends in Natural Sciences}

Vol. 9, Issue 17, pp. 153-159, 2020

https://doi.org/10.47068/ctns.2020.v9i17.018

Current Trends in Natural Sciences (on-line)

ISSN: 2284-953X

ISSN-L: 2284-9521
Current Trends in Natural Sciences (CD-Rom)

ISSN: 2284-9521

ISSN-L: 2284-9521

The value was evaluated by taking 15 plants from each variety and the average values collected during 2 years of study was performed. For each character, a maximum number of possible points to be awarded were established from 0-10, depending on the importance of that character and average, using the scale proposed by Wagner, 2002 (Table 1). The time interval between evaluations varied depending on the character. For the most important characters, evaluations were made every 14 days.

At the end of the vegetation period, the arithmetic means of the marks obtained for each analyzed character was calculated, by dividing the corresponding amounts by the number of assessments performed. Then the value of the variety was calculated by summing the averages of the traits by years. The values obtained were evaluated as follows: $90-100$ points - excellent; 80-90 points - very good; 70-80 points - good; 70 points -poor; 50-60 points - very poor. The final value of a rose variety, on average over two years (2018-2019), was obtained by summing the annual averages of the 13 characters evaluated.

Also, on the 10 varieties studied, some determinations were made regarding the phenological behavior on the important phenophases (budding, prefoliation, bud appearance and flowering), during the two years of study (Table 3 ).

Table 1. Evaluation sheet used for rose varieties in the TH group

\begin{tabular}{|l|c|c|}
\hline $\begin{array}{c}\text { No. } \\
\text { crt. }\end{array}$ & The character studied & Points \\
\hline 1 & Leaves & 10 \\
\hline 2 & Shrub shape & 5 \\
\hline 3 & Vigor & 5 \\
\hline 4 & Flower pedicel & 10 \\
\hline 5 & Flowering intensity & 10 \\
\hline 6 & Shape of the bud & 9 \\
\hline 7 & Shape of the open flower & 9 \\
\hline 8 & Flower durability & 6 \\
\hline 9 & Opening color & 6 \\
\hline 10 & Flowering color & 5 \\
\hline 11 & How to drop the petals & 7 \\
\hline 12 & Perfume & 8 \\
\hline 13 & Diseases resistance & \\
\hline
\end{tabular}

Source Wagner, 2002: 170

\section{RESULTS AND DISCUSSIONS}

Analyzing the studied Rosa hybrida Thea cultivars, the results obtained from the observations and determinations based on the evaluation sheets are presented in the table 2 . The total average of all cultivars studied was 84.2 points.

Analyzing table 2 the average of shrub shape of the analyzed rose varieties was 4.2 out of 5 maximum points. 'White Success' has reached the maximum score, which indicates that it has a compact, good-looking shrub. 
Current Trends in Natural Sciences

Vol. 9, Issue 17, pp. 153-159, 2020

https://doi.org/10.47068/ctns.2020.v9i17.018

Current Trends in Natural Sciences (on-line)

Table 2. Average evaluation for the 10 cultivars of Rosa hybrida TH, Ciumbrud 2018-2019

\begin{tabular}{|c|c|c|c|c|c|c|c|c|c|c|c|c|c|}
\hline \multirow{2}{*}{\multicolumn{2}{|c|}{ Characters }} & \multirow{2}{*}{$\begin{array}{c}\text { Nr. of } \\
\text { point } \\
\text { maximum }\end{array}$} & \multicolumn{10}{|c|}{ Average characters of cultivars } & \\
\hline & & & $\begin{array}{c}\text { Acapella } \\
\text { Tantau }\end{array}$ & $\begin{array}{l}\text { Caprice } \\
\text { Meilland }\end{array}$ & $\begin{array}{c}\text { Imperatrice } \\
\text { Farah }\end{array}$ & $\begin{array}{l}\text { Burdgund } \\
\text { ' } 81\end{array}$ & Monika & Romstar & $\begin{array}{l}\text { White } \\
\text { Succes }\end{array}$ & Vivaldi & $\begin{array}{l}\text { Black } \\
\text { Velvet }\end{array}$ & $\begin{array}{l}\text { Holstein } \\
\text { Perle }\end{array}$ & \\
\hline 1 & Shrub shape & 5 & 4.0 & 4.0 & 3.4 & 4.6 & 4.0 & 4.0 & 5.0 & 4.8 & 4.6 & 3.3 & 4.2 \\
\hline 2 & Vigor & 10 & 8.6 & 9.5 & 9.7 & 8.8 & 8.8 & 8.5 & 8.0 & 8.5 & 7.8 & 8.3 & 8.6 \\
\hline 3 & Leaf & 10 & 8.8 & 8.0 & 9.0 & 8.2 & 9.0 & 9.0 & 8.0 & 8.2 & 9.0 & 8.0 & 8.5 \\
\hline 4 & Flower stalk & 5 & 4.8 & 4.4 & 4.8 & 4.8 & 5.0 & 4.4 & 4.5 & 4.0 & 4.8 & 4.0 & 4.5 \\
\hline 5 & Flowering intensity & 10 & 6.8 & 7.9 & 7.1 & 8.1 & 9.0 & 8.0 & 8.8 & 7.9 & 8.6 & 7.6 & 8.0 \\
\hline 6 & Shape of the bud & 10 & 9.0 & 7.4 & 8.0 & 8.8 & 9.0 & 8.8 & 8.0 & 8.4 & 8.3 & 8.0 & 8.4 \\
\hline 7 & $\begin{array}{l}\text { Shape of the open } \\
\text { flower }\end{array}$ & 9 & 8.0 & 7.8 & 8.6 & 8.0 & 9.0 & 8.6 & 8.0 & 8.0 & 8.2 & 7.0 & 8.1 \\
\hline 8 & Flower durability & 9 & 6.3 & 7.0 & 7.2 & 8.1 & 6.5 & 7.0 & 7.1 & 7.5 & 7.8 & 6.5 & 7.1 \\
\hline 9 & Opening color & 6 & 6.0 & 6.0 & 6.0 & 6.0 & 6.0 & 6.0 & 6.0 & 6.0 & 6.0 & 6.0 & 6.0 \\
\hline 10 & Flowering color & 6 & 5.4 & 5.0 & 5.6 & 5.4 & 5.0 & 5.3 & 6.0 & 6.0 & 5.4 & 5.0 & 5.4 \\
\hline 11 & $\begin{array}{l}\text { How to drop the } \\
\text { petals }\end{array}$ & 5 & 4.0 & 3.6 & 4.0 & 3.1 & 5.0 & 4.0 & 4.0 & 4.0 & 4.3 & 2.8 & 3.9 \\
\hline 12 & Perfume & 7 & 6.0 & 5.3 & 2.0 & 5.6 & 4,0 & 6.0 & 4.0 & 3.0 & 3.0 & 1.2 & 4.0 \\
\hline 13 & Diseases resistance & 8 & 7.7 & 7.7 & 7.5 & 6.1 & 7.4 & 8.0 & 7.5 & 7.4 & 7.8 & 7.5 & 7.5 \\
\hline & TOTAL & & 85.4 & 83.6 & 82.9 & 85.6 & 87.7 & 87.6 & 84.9 & 83.7 & 85.6 & 75.2 & 84.2 \\
\hline
\end{tabular}

For vigor the maximum number of points is 10, the variety 'Imperetrice Farah' reached the value of 9.7 points, being the most valuable, followed by the variety 'Caprice de Meilland' with 9.5. The average of the varieties was at a score of 8.6 out of 10 maximum points.

In terms of leaves, the average score was 8.5, and there are four varieties that reached a score of 9.0 out of 10 maximum points ('Imperatrice Farah', 'Monika', 'Romstar' and 'Black Velvet ').

The average of flower pedicel was 4.5 points. Only the 'Monika' variety obtained a maximum rating of 5, while four varieties exceeded the average, obtaining a score of 8.0 ('Acapella Tantau', 'Imperatrice Farah', 'Burgundy 81', and 'Black Velvet').

None of the studied varieties reached a maximum score regarding the intensity of flowering. At this aspect with the highest score obtained by the variety 'Monika' with 9.0 points out of 10 .

Regarding the bud shape, two varieties, 'Acapella Tantau' and 'Monika', had reached the highest score of 9.0 points, compared to the variety 'Caprice de Meilland' which had only 7.4 points. The average points of this character were 8.4.

The shape of the open flower was appreciated with a good average of 8.1 out of a maximum of 9.0 points, which was the variety 'Monika'.

The durability of the flower is a very important character, mainly for the varieties that are recommended for cut flowers or to ensure a greater durability in landscape design. The average character was 7.1 out of a maximum 9 points.

The average of Color at flowering was 5.4 compared to 6 maximum points. The varieties 'White Success' and 'Black Velvet' reach the maximum score of 6.0.

The drop of the petals is a basic feature of roses. The maximum point for this character is 5 , being reached only by the variety 'Monika', and followed by 'Black Velvet' with a score of 4.3. At the opposite side the variety 'Holstein Perle' was positioned with a score of only 2.8 . 
The maximum number of points for perfume is 7 , but no variety has reached this scale. The 'Acapella Tantau' and 'Romstar' varieties get the highest score of 6, while the 'Holstein Perle' variety gathered only 1.2 points.

Similar research were made by Soujanya et al. (2018) who evaluated 25 Hybrid Tea rose for growth, yield and quality under eastern dry zone of Karnataka and the results revealed that there was significant variations among the varieties for growth, flowering and yield characters.

Table 3. Phenological behavior of 10 varieties of Rosa hybrida TH, Ciumbrud in 2019

\begin{tabular}{|l|l|c|c|c|c|c|c|}
\hline No. & \multicolumn{1}{|c|}{ Cultivars } & $\begin{array}{c}\text { Budding } \\
1\end{array}$ & $\begin{array}{c}\text { Prefoliation } \\
2\end{array}$ & $\begin{array}{c}\text { Burgeoning } \\
3\end{array}$ & $\begin{array}{c}\text { Flowering } \\
4\end{array}$ & $\begin{array}{c}\text { No days } \\
\text { between } \\
\text { phenophases } \\
1-3\end{array}$ & $\begin{array}{c}\text { No days } \\
\text { between } \\
\text { phenophases } \\
1-4\end{array}$ \\
\hline 1 & Acapella Tantau & 17 March & 2 April & 17 May & 1 June & 61 & 76 \\
\hline 2 & Caprice Meilland & 13 March & 30 March & 12 May & 26 May & 59 & 73 \\
\hline 3 & Imperatrice Farah & 15 March & 31 March & 19 May & 30 May & 61 & 72 \\
\hline 4 & Burdgund 81 & 14 March & 30 March & 22 May & 4 June & 69 & 81 \\
\hline 5 & Monika & 15 March & 1 April & 26 May & 10 June & 68 & 83 \\
\hline 6 & Romstar & 15 March & 29 March & 16 May & 2 June & 62 & 79 \\
\hline 7 & White Success & 17 March & 2 April & 27 May & 10 June & 71 & 85 \\
\hline 8 & Vivaldi & 16 March & 2 April & 24 May & 5 June & 69 & 80 \\
\hline 9 & Black Velvet & 14 March & 29 April & 14 May & 25 May & 62 & 73 \\
\hline 10 & Holstein Perle & 15 March & 29 March & 15 May & 28 May & 61 & 74 \\
\hline
\end{tabular}

Analysing the Table 3 regarding to the phenological behavior of 10 varieties of Rosa hybrida TH, Ciumbrud in 2019 can conclude:

The differences in the phenophase of prefoliation were 2-3 days between most varieties. The latest varieties blossomed every 3 days ('Acapella Tantau ', 'White Success` and 'Vivaldi ').

Considering the buds burgeoning, the 'Caprice de Meilland variety has been recorded earliest (May 12), and at the opposite side it was the 'White Success` variety (May 27).

The first rose variety that started flowering was the 'Black Velvet' on May 25 and the last variety was the 'Monika` on June 10.

Regarding the interval between the prefoliation and budding, we find in table 3 a difference of 59 days for the 'Caprice Meilland` variety and 71 days for the 'White Success` variety.

There were also differences recorded between the prefoliation and flowering, and the range was from 72 to 85 days at the `Imperatrice Farah` and 'White Success` varieties.

\section{CONCLUSIONS}

All varieties evaluated for the main characteristics have obtained an appropriate score (at least 70 points) will be proposed to be propagated and distributed in production. Based on this research, the value of the varieties can be established precisely, and useful recommendations can be given to the production sector. To multiply only those cultivars that meet the requirements of modern landscape 
architecture, which have the most demanding properties in terms of resistance to frost, disease and pests, and which cultivation is economically viable. The results obtained revealed the cultivars 'Monika', 'Romstar', 'Black Velvet' and 'Burgund 81', which after the evaluation obtained the highest score, over 85 points.

\section{ACKNOWLEDGEMENTS}

The authors gratefully acknowledge 'Super Rosa Csiki` Association for the research field and ornamental plant material supply. The present paper was published under the frame of the Collegium Talentum 2019 Programme of Hungary.

\section{REFERENCES}

Băla, M. (2012). Floricultură generală şi specială [General and Special Floriculture]. Ed. Partoş, (pp. 247-249), Timișoara.

Cantor, M. (2012). 'Grand Gala` - Trandafirul anului 2012 la Ziua rozelor de la Ciumbrud ['Grand Gala` - Rose of 2012 at the Rose Day in Ciumbrud], HORTImagazin 5: 44.

Ciupa, V., Szabo L.V. (2011). Roze de Timişoara [Roses of Timişoara], Ed. ArtPress, (pp. 31-34), Timişoara.

Haenchen, E. (2008). Cultura trandafirilor [Rose culture]. Ed. M.A.S.T. (pp. 7-8), Bucharest.

Hasek, R.F. (1980). Roses. In R.A. Larson, eds., Introduction to Floriculture, pp. 83-85. Academic Press, New York.

Kim Won, H. (2007). Rose. In J-M., Lee, G-W. Choi, J. Janick, eds., Horticulture in Korea, pp. 309-312, Suwon: Published by the Korean Society for Horticultural Science.

Mangandi, J., Park Brown, S., Peres, N. (2013). Evaluation of Low-maintenance Landscape Roses in Central Florida, HortTechnology, 23: Issue 2, 252-257.

Shivaprasad, S.G., Nataraj, S.K, Latha, S., Ravi, C.H., Suryakant, K. V. (2016). Evaluation and correlation studies of rose cultivars under naturally ventilated polyhouse, Res. Environ. Life Sci., 9(9), 1097-1099.

Soujanya, P., Balaji, S. K., Rajiv, K.., Munikrishnappa P.M., Shivapriya, M., Harshavardhan, M. (2018). Evaluation of rose (Rosa hybrid L.) varieties for growth, yield and quality under eastern dry zone of Karnataka. Journal of harmacognosy and Phytochemistry, 7(5), 165-168.

Toma, F. (2009). Floricultura şi Artă florală, vol. II: Specii utilizate pentru producerea florior tăiate [Floriculture and floral art, vol. II: Species used to produce cut flowers] Ed. INVELMultimedia, (pp. 61-70), Bucharest.

Wagner, St. (2002). Trandafirul de la mit la mileniul trei [The Rose-from myth to the third millennium], Ed. Echards Co. SNC, (pp. 8-10) Cluj-Napoca.

Wagner, Şt. (2013). Un nou soi de trandafir creat în România [A new variety of rose created in Romania, Rosarium 1 (year XXIII-45), 15, Cluj-Napoca.

http://www.worldrose.org/ 